\title{
USE OF GLIRICIDIA-ENRICHED LIQUID ORGANIC FERTILIZER FOR PRODUCTION OF CAISIM (Brassica juncea L.)
}

\author{
Alakhyar $^{1}$, Fahrurrozi Fahrurrozi $^{2 *}$, Widodo Widodo ${ }^{3}$, Dia Novita Sari ${ }^{4}$ \\ ${ }^{1}$ Former Student in Crop Production Department, Universitas Bengkulu, Bengkulu 38121, Indonesia \\ E-mail:alakhyar_poetrhamuni@yahoo.co.id \\ ${ }^{2}$ Crop Production, Universitas Bengkulu, Bengkulu 38121, Indonesia \\ *Corresponding Author, E-mail: fahrurrozi@ unib.ac.id \\ ${ }^{3}$ Crop Production Department, Universitas Bengkulu, Bengkulu 38121, Indonesia \\ Email: widodo@unib.ac.id \\ ${ }^{4}$ Closed Agriculture Production System (CAPS) Research Center, Faculty of Agriculture, \\ Universitas Bengkulu, Bengkulu 38121, Indonesia \\ Email:dia-ns@gmail.com
}

\begin{abstract}
Green biomass is one of major nutrient source and determines the quality of liquid organic fertilizer (LOF), including Gliricidia sepium (Jacq.) Kunth ex Walp. An experiment was conducted to study the effects of gliricidia-enriched LOF on growth and yields of caisim, arranged in randomized complete design with three replicates. Treatments consisted of six LOF concentrations, 0\%, 20\%, 40\%, 60\%, 80\% and 100\%. Results indicated that concentration of gliricidia-LOF significantly influenced leaf greenness and shoot fresh weight, but not root to shoot ratio and shoot water content. Concentrations of gliricidiaLOF increased leaf greenness and shoot fresh weight of caisim. The optimum concentration was $70.85 \%$ to produce weight of 73 grams caisim per plant. This yield of organically grown caisim was equal to 15.7 tons ha ${ }^{-1}$. However, root to shoot ratio was not significantly different. Although treatments did not affect shoot water content, all caisim water content was on average above $90 \%$.
\end{abstract}

Key words: Brassica juncea L; Gliricidia sepium; liquid organic fertilizer.

\section{INTRODUCTION}

Consumer demands for organically grown vegetables, including caisim (Brassica juncea L.), have been notably increasing during the last two decades since many people in all over the world are getting more educated and prosperous. Significant increases of worldwide organic foods took place in 1990s (Thompson, 2000) and continue to increases until the present time. According to Tanmay (2019), increased global production and consumption of both organic fruits and vegetables placed these commodities as the largest and fastest growing commodity in global organic food market. In addition, consumers are also willing to pay more for organic foods due to less use of pesticides and high nutritive value. Increased demand was also related to increased consumers' awareness about health benefits from organic vegetables. Such increases require continuous supply to the markets and hence organic vegetable production must be able to ensure the market demands without sacrificing the quality of land and water resources.

In organic vegetable production, the use of solid organic fertilizer has been widely practiced for nutrient supply to vegetable crops. Nevertheless, solid organic fertilizer often required more time to get mineralized than crop life-cycles (Hartz et al., 2000). Such characteristic endorses the use of liquid organic fertilizer (LOF) to fulfill nutrient required for organic crop production. This organic fertilizer is simply applied in soluble form instead of granular 


\section{DOI: https://doi.org/10.32663}

forms. The production of LOF used various organic materials, including animal manure, green biomasses, effective microorganisms, waterand other locally available elements. All composing materials were further incubated for three to four weeks for aerobic biological decomposition. The use of LOF has been successfully improved growth and yield of many vegetables, such as in lettuce (Surtinah et al., 2009), green cabbage (Nasution et al., 2014), cauliflower (Gomies et al., 2012), kailan (Sinaga et al., 2014), potato (Parman, 2007), tomato (Zhai et al., 2009) and sweet-corn (Pasaribu et al., 2011).

Green biomass is one of the main component to determine the effetiveness of liqud organic fertilizer for vegetable production since it served as one of nutrient sources in LOF. Fahrurrozi et al. (2017) has identified nutrient content of six potential green biomasses, included Tithonia diversifolia (Hemsl.) A.Gray, Gliricidia sepium (Jacq.) Kunth ex Walp., Leucaena leucocephala (Lamk.) de Wit, Ageratum conyzoides L., Eichhornia crassipes (Mart.) Solms, and banana corms. It was concluded that $G$. sepium is one of the most promising green biomassfor LOF production after $A$. conyzoides and T.diversifolia since leaves of $G$. sepium preserved higher level of $\mathrm{N}$ and $\mathrm{P}$ compared to others. It was reported that nutrient content of $G$. sepium leaves contained $16.8 \%$ of dry matter, $5.04 \%$ of N, $0.32 \%$ of $\mathrm{P}, 6.21 . \mathrm{mg} / 100 \mathrm{mg}$ of $\mathrm{K}, 12.83 \mathrm{me} / 100 \mathrm{~g}$ of exchangeable $\mathrm{Ca}, 5.83 \mathrm{me} / 100 \mathrm{~g}$ of $\mathrm{Mg}$, $47.74 \%$ of organic C, $11.89 \%$ of cellulose and 6.105 of lignin. Previously, Agus and Widianto (2004) revealed that leaves of $G$. sepium contained 36.9 to $40.7 \%$ organic C, 3 to $6 \% \mathrm{~N}, 1$ to $3 \% \mathrm{P}, 0.77 \% \mathrm{~K}, 15$ to $30 \%$ fibre, 1.9 to $3.2 \% \mathrm{Ca}$ and $10 \% \mathrm{~K}$ ash.

In addition to type of green biomass, crop species, fertilizer form, frequency of application and the stage of plant growth, concentration of LOF applied to vegetable crops, is among the key factor to determine the successfulness of LOF application
(Haytova, 2013). Research conducted by Oviyanti et al., (2016) concluded that the use of gliricidia-enriched LOF increased growth of Brassica junceaL., but no reports of yields (fresh weight). The use of gliricidia-enriched LOF to increase caisim (Brassica juncea L.) production has been very limited reported elsewhere. This experiment aimed to determine the effects of gliricidia-enriched LOF concentrations in yields of caisim vegetable.

\section{MATERIALS AND METHOD}

The experiment was established from April to June 2016 in the experimental site of Faculty of Agriculture, University of Bengkulu at the elevation of \pm 10 meter above sea level. Experiment was arranged in complete randomized design with three replicates. Treatments consisted of six gliricidia-LOF concentrations, $0 \%$ (no LOF), 20\% LOF, $40 \%$ LOF, $60 \%$ LOF, $80 \%$ LOF and $100 \%$ LOF. Each treatment consisted of four sample plants grown in each individual polybag.

Production of gliricidia-LOF was conducted by mixing $5 \mathrm{~kg}$ fresh cattle's feces, 10 cattle's urine, $2.5 \mathrm{~kg}$ of topsoil, 5 $\mathrm{kg}$ of G. sepium leaves, 101 solution of 24hour incubated $10 \mathrm{ml} \mathrm{EM} 4+0.125 \mathrm{~kg}$ white sugar in a blue plastic container to make incubated LOF mixture. These mixtures were added with water to reach a volume of 1001 , securely covered and incubated for five weeks.

Growing media was arranged in black polyethylene polybags contained 2 $\mathrm{kg}$ of top soil of ultisol and mixed with 2 $\mathrm{kg}$ of cattle based organic fertilizer. Two caisim ( $c v$. DORA) seedlings of two weeks old were transplanted into the polybags, and then a worse seedling was removed from the polybag to leave a single plant in each polybag.

Every single plant received a total of $400 \mathrm{ml} \mathrm{LOF}$ according to treatments and was sprayed uniformly to plants as much as $60 \mathrm{ml}, 80 \mathrm{ml}, 100 \mathrm{ml}$ and $160 \mathrm{ml}$ at 5 , 


\section{DOI: https://doi.org/10.32663}

10, 15 and 20 days after transplanting, respectively. Plants were manually irrigated, when there was no precipitation, until the growing medium reached field capacity, indicated by dripping water from the bottom of polybag. All weeds, pests and diseases were physically controlled by removing their presence in the polybags.

The effect of treatments on caisim growth was measured by leaf greenness (SPAD indicator) at 25 days after transplanting. Crops were harvested at 30 days after transplanting, cleaned and its roots was removed, and weighed to get its fresh weight plant $^{-1}(\mathrm{~g})$. Treatment effects were also observed in terms of root to shoot and shoot water content (\%).Data were statistically analyzed by using PROC GLM in Statistical Analysis System at P < 0.05 . Orthogonal polynomial tests at $\mathrm{P}<$ 0.05 were addressed to determine the relationship between significant variables with treatments.

\section{RESULTS AND DISCUSSION}

Data from closest Meteorological Station during the experiment indicated that average of monthly precipitation, air temperatures and air humidity from April to June were $344.5 \mathrm{~mm}, 27.6{ }^{\circ} \mathrm{C}$ and $85 \%$, respectively. Results indicated that concentration of gliricidia-LOF significantly influenced leaf greenness (Pr. $>\mathrm{F}=0.0230)$ and shoot fresh weight $\operatorname{Pr} .>\mathrm{F}=0.0014)$ but not root to shoot ratio (Pr. $>\mathrm{F}=0.8745)$ and shoot water content (Pr. $>\mathrm{F}=0.6424)$.

Concentration of gliricidia-LOF significantly increased leaf greenness was (Pr. $>\mathrm{F}=0.042$ ) with linear equation of $\mathrm{y}=0.0563 \mathrm{x}+37.219$ and $\mathrm{R}^{2}=0.3576$ (Figure 1). Leaf greenness reflects the concentration of chlorophyll presence in the chloroplasts and its amount determines rate of crop photosynthesis. Increased leaf greenness might be related to nutrient content in G. sepium leaves with high $\mathrm{N}$ and $\mathrm{Mg}$ contents (Fahrurrozi et al., 2017). Both $\mathrm{N}$ and $\mathrm{Mg}$ are responsible in biosynthesis of chlorophyll in the chloroplasts (Taiz and Zeiger, 2010). Nevertheless, this research suggested that only $35.76 \%$ of leaf greenness was determined by LOF application. LOF application could have been better if its application was accompanied with the use of surfactant liquid for better retention of foliar application, for example in muskmelon (Lester et al., 2006), onion (Safikhani et al., 2018) and in tomato (Haleema et al., 2018). Surfactants might increase LOF penetrations through leaf stomata and cuticles reaching leaf cells (Fernandez and Eichert, 2009) and eventually increased chlorophyll contents (as indicated by leaf greenness). Finding a suitable organic surfactant for organically grown vegetables by using green mass available in surrounding production site would be a future project can be addressed. Values of leaf greenness of caisim from this experiment were somehow comparable with that of reported by Yanda et al. (2018), where leaf greenness of caisim plants grown under open field ranged from 40 to 45 , while leaf greenness under shading condition ranged from 31 to 33 .

Shoot fresh weight of caisim is very important traits since this part determines the economic value of this vegetable. Result from this experiment indicated that concentration of gliricidia-enriched LOF increased shoot fresh weight of caisims (Pr. $>\mathrm{F}=0.0155)$ with quadratic relationship of $\mathrm{y}=-0.0071 \mathrm{x}^{2}+1.1188 \mathrm{x}+28.47$ and $\mathrm{R}^{2}=0.6978$ (Figure 2). Results suggested that the optimum LOF concentration was $70.85 \%$ to produce weight of 73 grams caisim per plant. Assuming total plants ha ${ }^{1}$ of 215.500 plants, this concentration produced more than 15.7 tons caisim $\mathrm{ha}^{-1}$. Nevertheless, this yield was somehow lower than its variety description which ranges from 20 to 25 tons $\mathrm{ha}^{-1}$. Although this figure was lower, this number was not bad since it was organically produced. Meanwhile the variety description was determined based on conventional 


\section{DOI: https://doi.org/10.32663}

production systems by using synthetic fertilizer and pesticides.

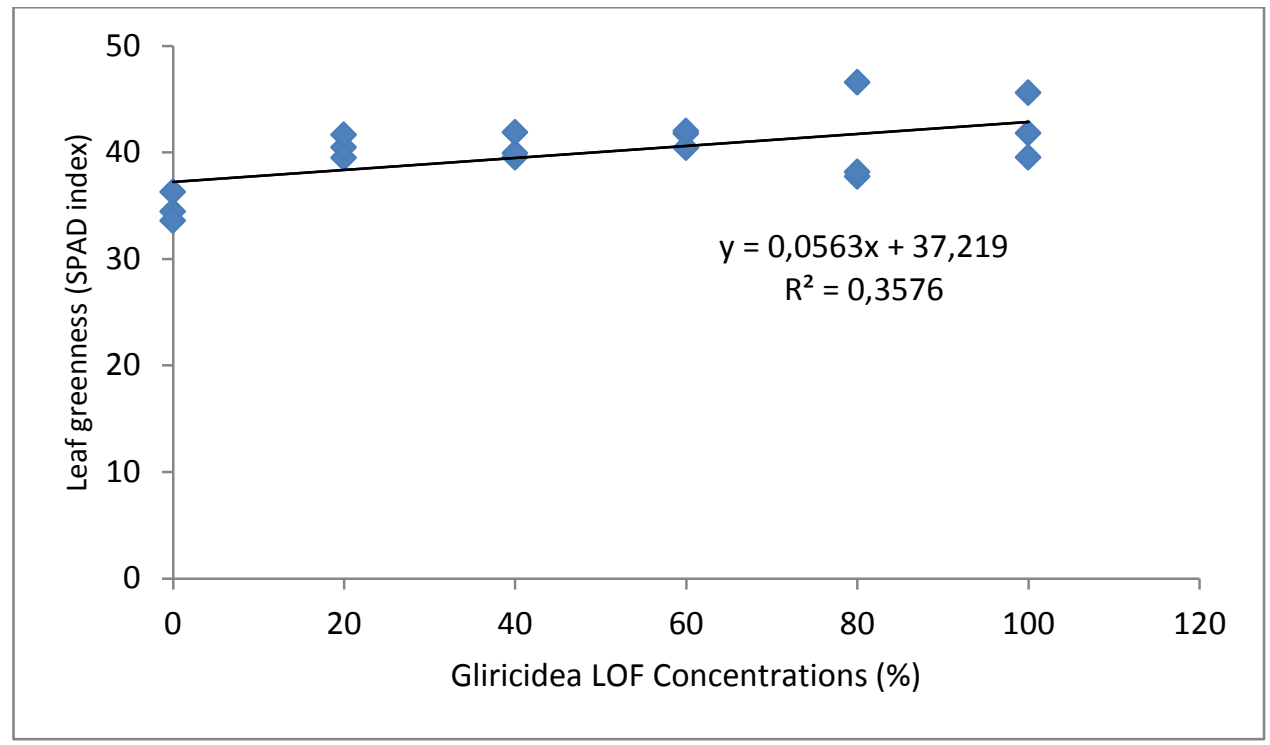

Figure 1. Relationship between concentrations of gliricidia-enriched LOF fertilizer and leaf greenness

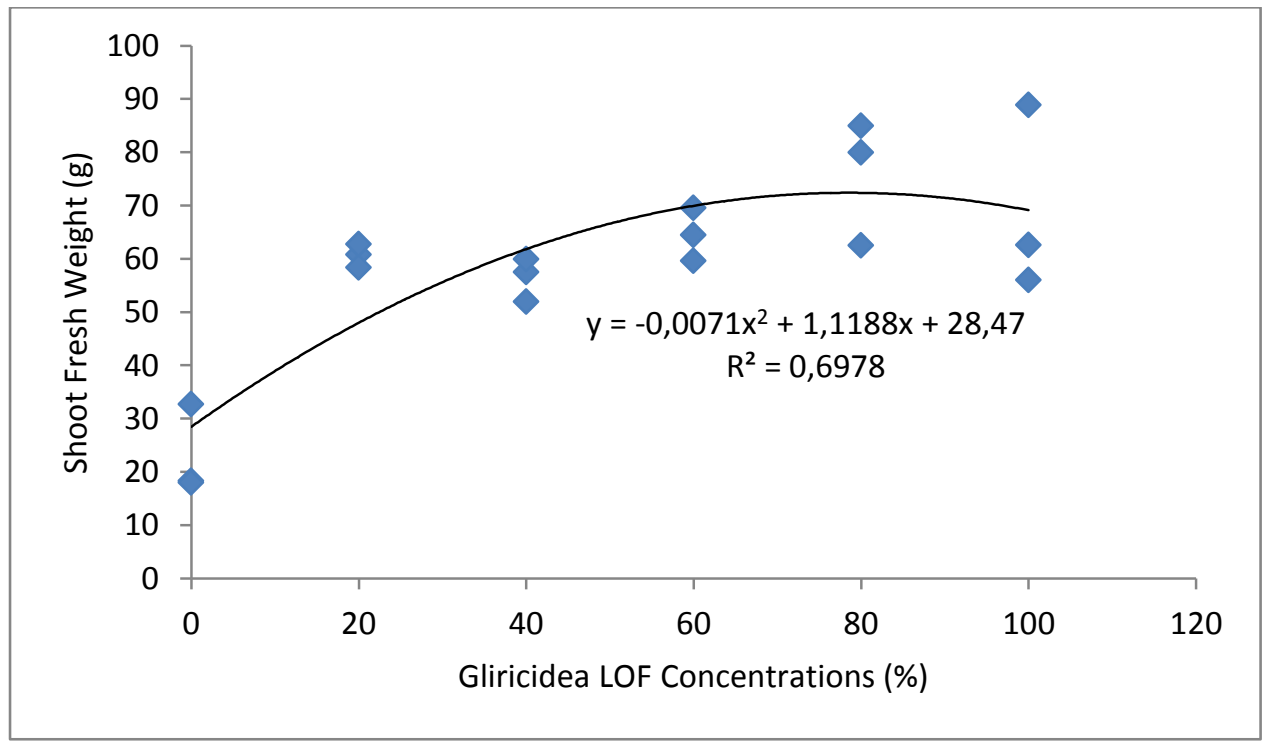

Figure 2. Relationship between concentrations of gliricidia-enriched LOF and shoot fresh weight of caisim

Increased caisim fresh weight might have attributed to nutrient in LOF increased fresh weight. Although this experiment did not analyse nutrient content of gliricidiaLOF, research conducted by Oviyanti et al. (2016) found that gliricidia-LOF contained $0.24 \%$ of nitrogen, 0.039 of P-total, $8.38 \%$ of potassium $(\mathrm{K})$ and $12.4 \%$ of organic $\mathrm{C}$. High potassium content and organic $\mathrm{C}$ might have contributed to increased caisim fresh weight.The presence of $\mathrm{K}$ in LOF is very important as this nutrient plays important roles in increasing disease resistance, strengthening cell walls 


\section{DOI: $\underline{\text { https://doi.org/10.32663 }}$}

(Marchsners, 2012) and involves in more than 60 types of growth enzymes (Potash and Potassium Institute, 1998) which eventually increased crop yields. According to Karamanos (2013) higher levels of potassium will increase the ability of plant to convert nitrogen into protein. Sathiamoorthy and Jeyabaskaran (2001) emphasized the importance of potassium in organic farming for successful crop yield and development. In addition, sufficient potassium supply is a necessity to maintain good water use efficiency, reduce pest problems and increase harvest quality (Mikkelsen, 2008). Increased caisim fresh weight might have also related to increased leaf greenness of caisims (Figure 1) which eventually increased caisim photosynthesis.

It appeared that foliar application of gliricidia-LOF to caisim effectively absorbed by leaf surfaces and eventually increased leaf and stem growth and development. Foliar application improved the effectiveness of liquid fertilizer penetrations into leaf cells through leaf stomata and hydrophilic pores present on the leaf cuticles (Fernandez and Eichert, 2009) and eventually improved aboveground parts. Broad leaf vegetables, including caisim, have better response to foliar application compared to narrow leaf vegetables (Hagin and Tucker, 1982). Other research conducted by Dela-Pena $e t$ al. (2013) concluded that tithonia-enriched LOF increased fresh weight pechay plant (Brassica rapa L.), a leafy vegetable. In addition, the use of local based LOF successfully increased yields of broad-leaf vegetables such as lettuce (Surtinah, 2009) and Chinese green cabbage (Nasution et al., 2014).

Root to shoot ratio might reflect the ability of root to support aboveground (shoot) growth and development. Although gliricidia-LOF concentration significantly affected shoot fresh weight of caisim, ratio of root to shoot ratio (RSR) of caisim was not significantly affected $(\mathrm{Pr} .>\mathrm{F}=0.8745)$.

Results indicated that RSR of caisim ranged from 0.06 to 0.08 (Figure 3A). Although root growth involves complex interactions between plants, soil nutrients, microorganisms and soil physical aspects, this experiment suggested gliricidia-LOF also had more effect on aboveground parts of caisim plants. Such effect is very important to leafy vegetables, including caisim, because above ground parts (leaves and stems) of this type of vegetable determine its economic values.

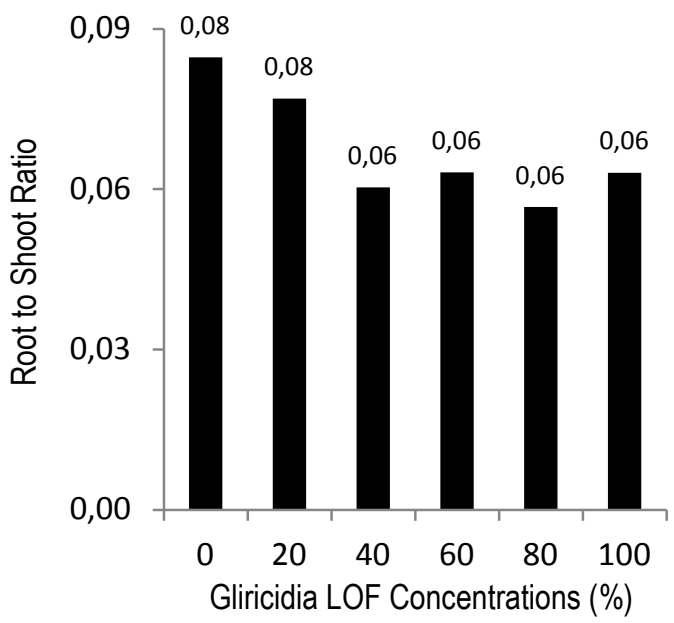

A

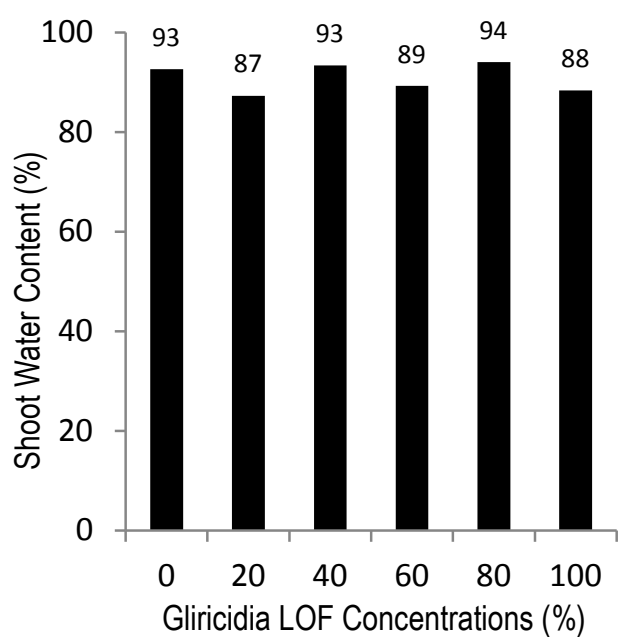

B

Figure 3. Effects of gliricidia LOF concentration on shoot root ratio (A) and shoot water content of caisim (B) 


\section{DOI: https://doi.org/10.32663}

Water content of vegetable is very important trait since it determines vegetable freshness which eventually influences the selling price and consumer preferences. This experiment revealed that concentration gliricidia-LOF did not influence shoot water content of caisim (Pr. $>\mathrm{F}=0.6424)$. Nevertheless, shoot water contents of caisim from this experiment ranged from 87 to $94 \%$ (Figure 3B). These numbers were comparable to caisim water content as affected by the liquid organic fertilizer with the magnitudes ranged from 89 to $92 \%$ (Winarsih et al., 2012).

\section{CONCLUSIONS}

The use of gliricidia-LOF significantly increased leaf greenness and shoot fresh weight of caisim plants. The optimum concentration was $70.85 \%$ to produce organically grown caisim of more than 15.7 tons $\mathrm{ha}^{-1}$. Such number was almost $78.5 \%$ of caisim yields grown with non-organic production systems. In addition, gliricidia-LOF have more effect of on above ground part of caisim than that of below ground parts as indicated by root to shoot ratio. Although treatments did not affect shoot water content, all caisim water content was on average above $90 \%$.

\section{ACKNOWLEDGEMENT}

Authors would like to sincerely thank Department of Crop Production, Faculty of Agriculture, University of Bengkulu for providing space and equipment during the course of experiments

\section{REFERENCES}

Agus, F. \& Widianto. 2004. Petunjuk Praktis Konservasi Tanah Pertanian Lahan Kering. World Agroforestry Centre. ICRAF. SoutheastAsia.

Dela-Pena, C., Bartolome, D.L.I. \& Banwa, T.P. 2013. The potential of Tithonia diversifolia (Wild Sunflower) as organic foliar fertilizer. European Scientific Journal, 4, 465-468.
Fahrurrozi F, Sariasih Y, Muktamar Z, Setyowati N, Chozin M \& Sudjatmiko S. $2017 . \quad$ Identification of nutrients content in six potential green biomasses for developing liquid organic fertilizer in closed agricultural production system. International Journal on Advanced Science, Engineering, Information Technology, 7:559-565.

Fernadez, V. \& Eichert, T. 2009. Uptake of hydrophilic solutes through plant leaves: current state of knowledge and perspectives of foliar fertilization. Critical Rev. in Plant Sciences, 28, 36-68.

Gomies, L., Rehatta, H. \& Nandissa, J. 2012. Pengaruh pupuk organik cair ril terhadap pertumbuhan dan produksi tanaman kubis bunga (Brassica oleraceaVar. Botrytis L.). Agrologia, 1, 13-20.

Hagin, J. \& Tucker, B. 1982. Fertilization of dryland and irrigated soil. Springs-verlag, Berlin. HelderbergInc, Germany.

Haleema, B., Rab, A., \& Hussain, S.A. 2018. Effect of calcium, boron and zinc foliar application on growth and fruit production of tomato. Sarhad Journal of Agriculture, 34(1), 19-30.

Hartz, T.K., Mitchel, J.P. \&Giannini, G. 2000. Nitrogen and carbon mineralization dynamics of manures and composts. HortScience, 35, 209-212.

Haytova, D. 2013. A Review of Roliar Fertilization of Some Vegetable Crops. Annual Review and Research in Biology, 3, 455-465.

Karamanos, R. E. 2013. Nutrient uptake and metabolisms in crops. Praire Soils and Crops Journal 6:52-63.

Lester, G. E., Jifon, J. L., \& Makus, D. J. 2006. Supplemental foliar potassium applications with or without a surfactant can enhance netted muskmelon quality. HortScience, 41(3), 741-744.

Marschner, H. 2012. Marschner's mineral nutrition of higher plants. 3rd ed. London. Academic Press, pp. 649

Mikkelsen, R. 2008. Managing potassium for organic crop production. Better Crops with Plant Food. A Publication of the International Plant Nutrition Institute (IPNI) 92:26-29.

Nasution, F.J. Mawarni, L. \& Meiriani. 2014. Aplikasi Pupuk Organik Padat dan Cair dari Kulit Pisang Kepok untuk 


\section{DOI: https://doi.org/10.32663}

Pertumbuhan dan Produksi Sawi (Brassica juncea L.). Program Studi Agroekoteknologi Fakultas Pertanian, USU. Medan. Online Agroekoteknologi. 1, 1029-1037.

Oviyanti, F., Syarifah, \& Hidayah, N. 2016. Pengaruh pemberian pupuk cair daun gamal (Gliricidia sepium (Jacq.) Kunth ex Walp.) terhadap pertumbuhan tanaman sawi (Brassica juncea L.). Jurnal Biota, 2, 61-67.

Parman, S. 2007. Pengaruh pemberian pupuk organik cair terhadap pertumbuhan dan produksi kentang (Solanum tuberosum L.). Buletin Anatomi dan Fisiologi, 15, 21-31.

Pasaribu, M.S., Barus, W.A.\&Kurnianto, H. 2011. Pengaruh konsentrasi dan interval waktu pemberian pupuk organik cair (poc) nasa terhadap pertumbuhan dan produksi jagung manis (Zea mays Saccharata Sturt). Agrium, 17 (1), 46-52.

Potash and Phosphate Institute. 1998. Potassium for Agriculture. Better Crops with Plant Food. A Publication of the International Plant Nutrition Institute (IPNI). No. 3. pp. 40.

Safikhani, S. M.R. Chaichi \& M. Mohammadi. 2018. Surfactant application improves growth and development of onion (crystal white var.) in saline soil. Advances in Plants \& Agricultural Research, 8(3), 241 245.

Sathiamoorthy, S. and K.J. Jeyabaskaran. 2001. Potassium management of banana. IPI/NARCTT Regional Workshop: Potassium and Water Management in West Asia and North Africa, Amman (JOR). pp. 499-516.
Sinaga, P., Meiriani \& Hasanah, Y. 2014. Respons pertumbuhan dan produksi kailan (brassica oleraceae 1.) Pada pemberian berbagai dosis pupuk organik cair paitan (Tithonia diversifolia Hemsl.) Gray). Program Studi Agroekoteknologi, Fakultas Pertanian, USU, Medan. Online Agroekoteknologi, 2, 584-588.

Surtinah. 2009. Pemberian pupuk organik super natural nutrition (SNN) pada tanaman selada (Lactuca sativa L.) di tanah Ultisol. Ilmiah Pertanian, 6, 1-9

Taiz, L. \& Zeiger, E. 2010. Plant Physiology. $5^{\text {th }}$ Edition, Sinauer Associates Inc., Sunderland, $782 \mathrm{p}$.

Tanmay, H. 2019. Organic Fruits And Vegetables Market 2019 - Increasing Demand, Growth Analysis and Future Outlook 2023.

Thompson, G. 2000. International Consumer Demand for Organic Foods. HorTechnology, 10(4), 663-674.

Winarsih, D., Prihastanti, E. \& Saptaningsih, E. (2012). Kadar serat dan kadar air serta penampakan fisik produk pasca panen daun caisim (Brassica juncea L.) yang ditanam pada media dengan penambahan pupuk organik hayati cair dan pupuk anorganik. Bioma, 14, 25-32.

Yanda, Y.S.O, Fahrurrozi, F., \& Supanjani, S. (2018). Growing caisim (Brassica juncea L.) using elaeisponic production system, Akta Agrosia, 21, 1-4.

Zhai, Z., Ehret, D.L., Forge, T., Lin, W., Dorais, M.\&Papadopoulos, P.A. 2009. Organic fertilizers for greenhouse tomatoes: productivity and substrate microbiology. HortScience, $\quad 44, \quad 800-809$. 